$\xi=-1$

\title{
Structural Behavior of Unbalanced Section self-compacting reinforced concrete axially Loaded columns
}

\author{
Aamer Najim Abbas ${ }^{*}$, Nura Jasim Muhammed $^{2 * *}$ \\ ${ }^{1,2}$ Civil Engineering Department, Al-Mustansiriyah University, Baghdad, Iraq \\ *Corresponding author E-mail: amir_najim@uomustansiriyah.edu.iq \\ **authorE-mail: nura_jacob@uomustansiriyah.edu.iq
}

\begin{abstract}
Eight $(120 \mathrm{~mm})$ square and $(1 \mathrm{~m})$ long reinforced concrete columns were tested under axial load to large inelastic deformations. The main purpose of this research was to investigate the behavior of column sections confined by rectilinear ties. Major variables considered in this program included: (1) Distribution of longitudinal and lateral steel, including unbalanced section due to the asymmetric distribution of reinforcing steel bars (2) type of concrete; normal concrete and self-compacting concrete. Finite element model was performed to validate the experimental results of this investigation. Test results indicate that a asymmetric distribution longitudinal bars results in desired performance of columns. Unsupported longitudinal bars and its number effective only at large deformations and result in rapid deterioration of column behavior at a later stage. There is $8.75 \%$ and $35.65 \%$ decrease in ultimate capacity under the control column, asymmetric distribution of reinforcing steel bars appears a more brittle while symmetric bars yields more elastic than brittle, it adds safety when failure happens.
\end{abstract}

Keywords: confinement, ultimate load, first crack load, stiffness, ANSYS, longitudinal reinforcement, column.

\section{Introduction}

Under lateral confinement processed by lateral reinforcing steel bars, improvement in the axial behavior of concrete has been emphasized owing to its beneficial effects on member capacity, ductility and stiffness of members (Watson and Zahn 1994 ), (Bai et.al). Several researchers deal with the ways for confining the concrete core of reinforced concrete columns. (Patrick et.al 2005) and (Omar M. Y. M. et.al 2010) increased the ratio of transverse reinforcement in addition to use the self-compacting concrete to enhance the column behavior through keeping the concrete core from crushing. (Silvia et.al 2006) and (Chikh N. et.al 2012) used carbon fiber strips to avoid crushing the concrete of columns. Depending on the neutral axis position inside the section, different combinations of internal moment and forces can be appeared, such combinations is called plastic limit envelope in the space of internal forces (also called the yield surface, yield locus, failure envelope, or interaction curve) (Preekanth 2015). Because of the unsymmetrical structural concrete section and distribution of the longitudinal bars in the cross section of the column, the internal compressive force can be resisted by the reinforcing steel bars located in the compression zone, in addition to the concrete. Moreover, the reinforcing steel bars can substantially confine the concrete core in the compression zone. Meanwhile, the longitudinal bars in the tension zone can provide the corresponding tensile force. Therefore, the hysteresis curves of the columns under a positive bending moment are very stable, especially demonstrated in the specimens with low axial load. Slight strength degradation was observed due to minor crushing of the concrete (Vigneshvar et. al 2017), (Tirath et. al 1995) and (Haider O. A. 2013).

This investigation deals with uneven distribution of reinforcing steel bars for two types of reinforced concrete square columns; normal strength and self-compacting concrete. A total of 8 concrete columns specimens were cast and tested under axial load. The experimental data recorded included the ultimate load, cracking load, and lateral deflection. The parameters considered are the number of reinforcing steel bars and uneven distribution of longitudinal steel bars.

\section{Materials And Methods}

The experimental program consists of eight of square columns; four columns manufactured with normal strength concrete and the other column manufactured with self-compacted concrete columns. All columns have a total height of $1000 \mathrm{~mm}$ and a cross section of $120 \times 120 \mathrm{~mm}$. A clear cover of $10 \mathrm{~mm}$ thickness was provided to all specimens. Each specimen of normal strength and self-compacted concrete has longitudinal reinforcement different than others; difference in amount and distribution of reinforcing steel bars. Figure (1) shows the reinforcement configurations of the tested specimens.

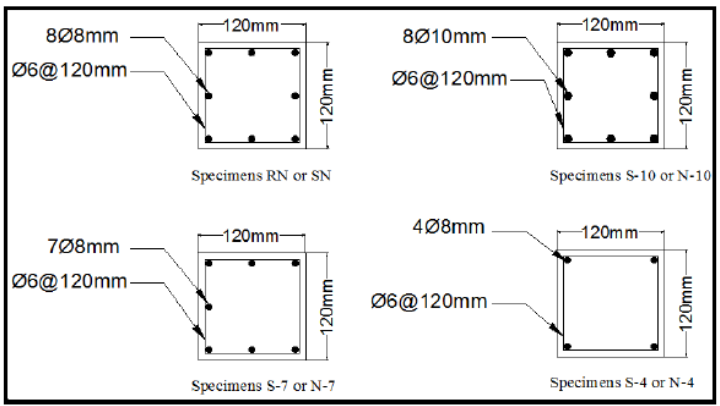

Fig.1: Reinforcement Configurations of Specimens 


\section{1. Mix Proportions}

The design cube compressive strength of the self-compacting concrete was $45 \mathrm{MPa}$ after 28 days. The concrete mix consists of 385 $\mathrm{kg} / \mathrm{m} 3$ cement content, $200 \mathrm{~L} / \mathrm{m} 3$ water, $165 \mathrm{~kg} / \mathrm{m} 3$ limestone, 635 $\mathrm{kg} / \mathrm{m} 3$ sand, $637.5 \mathrm{~kg} / \mathrm{m} 3,1085$ crushed gravel and finally $5 \%$ super plasticizer. The fresh concrete had a $550 \mathrm{~mm}$ slump flow; it was closed to self-compacting concrete.

The cube compressive strength of normal concrete columns was (30) after 28 days. The mix proportion consist of $385 \mathrm{~kg} / \mathrm{m} 3 \mathrm{ce}-$ ment content, $517 \mathrm{~kg} / \mathrm{m} 3$ sand, $1155 \mathrm{~kg} / \mathrm{m} 3$ gravel and $175 \mathrm{~L} / \mathrm{m} 3$ water. The properties of cement, sand and gravel used in this study are listed in Tables (1) to (4) below.

Mixing is performed using a concrete drum mixer. Wooden forms were prepared for casting the concrete. Concrete was cast in under control laboratory conditions of 25 OC temperatures. The specimens were cured after de-molding.

Table 1: Properties of Cement

\begin{tabular}{|l|c|}
\hline \multicolumn{1}{|c|}{ Physical properties } & Test result \\
\hline Fineness $\left(\mathrm{kg} / \mathrm{m}^{2}\right)$ & 2830 \\
\hline Soundness & 0.18 \\
\hline Initial setting time (min) & 70 \\
\hline Final setting time (hrs:min) & $3: 35$ \\
\hline Compressive strength (3 days) $(\mathrm{MPa})$ & 23.4 \\
\hline Compressive strength (7 days) $(\mathrm{MPa})$ & 35.1 \\
\hline
\end{tabular}

Table 2: Physical Properties of Fine Aggregate

\begin{tabular}{|l|c|}
\hline \multicolumn{1}{|c|}{ Properties } & Test result \\
\hline Water absorption & $0.53 \%$ \\
\hline Specific gravity & $2.39 \%$ \\
\hline Fineness modulus & 2.3 \\
\hline Moisture content & $0.24 \%$ \\
\hline
\end{tabular}

Table 3: Sieve Analysis of Fine Aggregate

\begin{tabular}{|c|c|}
\hline Sieve size & Passing ratio (\%) \\
\hline 9.5 & 100 \\
\hline 4.75 & 91 \\
\hline 2.36 & 79 \\
\hline 1.18 & 69 \\
\hline 0.6 & 22 \\
\hline 0.3 & 16 \\
\hline 0.15 & 1 \\
\hline
\end{tabular}

Table 4: Sieve Analysis of Coarse Aggregate

\begin{tabular}{|c|c|}
\hline Sieve size (mm) & \% Passing by weight \\
\hline 20 & 100 \\
\hline 14 & 99 \\
\hline 10 & 59 \\
\hline 5 & 4.2 \\
\hline 2.36 & 0 \\
\hline
\end{tabular}

\subsection{Reinforcing Steel}

Deformed cold worked reinforcing steel bars having $6 \mathrm{~mm}$ and 8 $\mathrm{mm}$ diameter were used in the construction of all specimens. Tension tests were performed on steel samples of each bar size. The mechanical properties of steel bars are given in the Table (5).

\begin{tabular}{|c|c|c|}
\multicolumn{3}{c}{ Table 5: Properties of Steel Bars } \\
\hline Bar size (mm) & $\begin{array}{c}\text { Yield strength (fy) } \\
(\mathbf{M P a})\end{array}$ & $\begin{array}{c}\text { Ultimate strength (Fu) } \\
\text { (MPa) }\end{array}$ \\
\hline $6 \mathrm{~mm}$ & 491 & 629 \\
\hline $8 \mathrm{~mm}$ & 479 & 594 \\
\hline
\end{tabular}

\subsection{Mechanical Properties of Concrete}

\subsubsection{Compressive Strength Test}

Cubical $(100 * 100) \mathrm{mm}$ specimens were used to test compressive strength of concrete at (28) days. The compressive test was done according to ASTM C39 [8] and B.S1881[9] by using a computerized machine with a capacity of $(1000 \mathrm{KN})$.

\subsubsection{Tensile Strength Test}

The splitting tensile strength is determined at (28) days on cylinder measuring $(150 * 300) \mathrm{mm}$ according to BS1881: part (117) [10]. The test results shown in Table (6).

Table 6: Tensile strength of concrete specimens

\begin{tabular}{|l|c|}
\hline Sample No. & Tensile Strength (MPa) \\
\hline Normal Concrete & 3.1 \\
\hline Normal Concrete & 3.22 \\
\hline Normal Concrete & 3.31 \\
\hline Normal Concrete & 3.16 \\
\hline Self-compacted Concrete & 3.62 \\
\hline Self-compacted Concrete & 3.49 \\
\hline Self-compacted Concrete & 3.63 \\
\hline Self-compacted Concrete & 3.71 \\
\hline
\end{tabular}

\subsection{Load Application}

The load has been applied gradually each $5 \mathrm{kN}$ vertically on perpendicular direction on column section. The machine base on the bottom has installed the specimen and hydraulic jack on the top see Figure (2). The lateral displacement was measured by dial guage installed on the side of column at mid height.

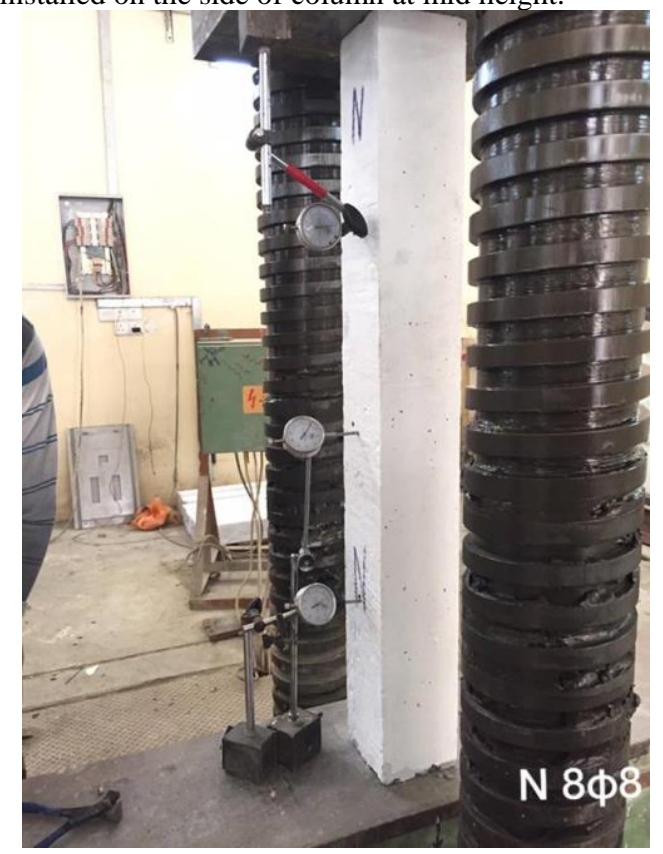

Fig. 2: Loading Set up

\section{Results and Discussions}

\subsection{Mode of Failure:}

All specimens (Normal strength and self-compacted) had a failure at the top and bottom ends due to crushing of the concrete, see Figure (3). Additionally, fragments of concrete cover were appeared at the mid-height of normal concrete specimens N4 and N7 with longitudinal reinforcement $4 \phi 8$ and $7 \phi 8$ respectively. The crushing mechanism starts at the top and bottom by thin cracks, 
these cracks were increased in width and length creates together fragments area, these cracks leading to the separation of the concrete cover, see Figure (4).

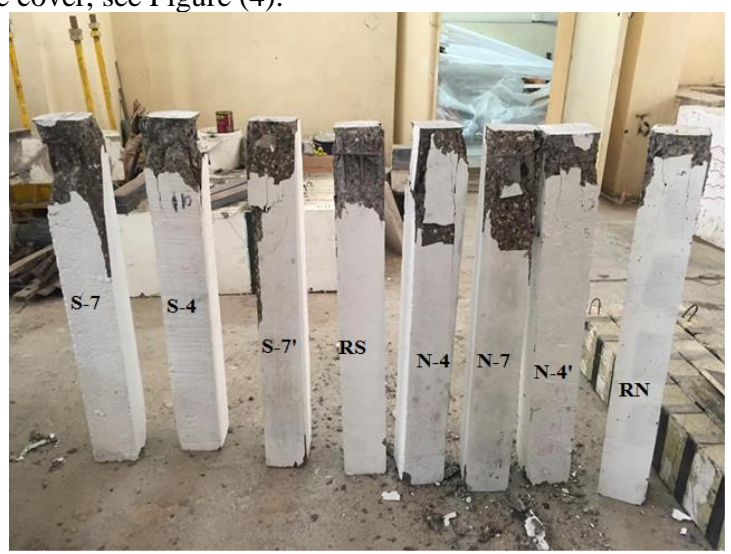

Fig. 3: Failure Pattern
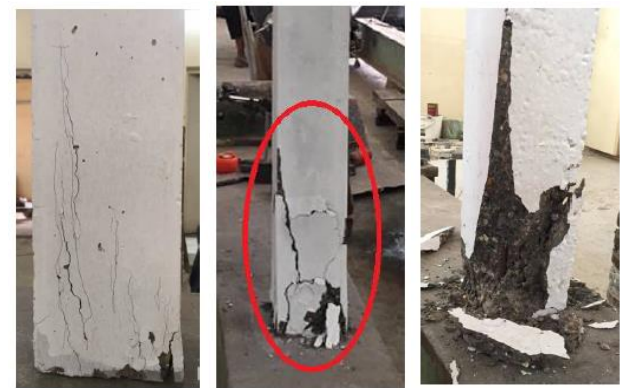

Fig. 4: Stages of Failure

\subsection{Load Versus Deflection Relationship}

The displacement were measured from zero load upward till failure of specimens, Figures (5) and (6) show that for normal strength concrete and self-compacted concrete respectively, the load-displacement curve is almost linear up to the value of first crack load. This stage is characterized by high stiffness of all tested columns; the amount of deformations that results from loading is slight compared to the following stages. This stage is classified as an elastic stage of specimen behavior. At this stage, all specimens are close in terms of deflections except for the specimens that have the least ratio of longitudinal reinforcing steel $(4 \phi 8)$ in specimens N-4 and S-4. After first cracks, the specimen continue with linear behavior and the slops of load-deflection curves continue to decrease until yielding of reinforcing steel as a result to the reduction of the specimens stiffness. The reduction in stiffness can be attributed to propagation of cracks in addition to the appearance of new cracks in different places of the specimens. At the advanced loading stages, nonlinear relationships between load and deflection were took place; the specimens continue to loss its stiffness until failure of the specimens. The failure is ductile in reference specimens $(\mathrm{RN})$ and (RS) in addition to specimens N-7 and S-7' (reinforced with 7\$10), while the failure of specimens $\mathrm{N}$ 4 and S-4 (reinforced with $4 \phi 8$ ) was brittle and sudden without warning because the fact that the available reinforcing bars was not efficient in confining the concrete at the column core.

Because of the unsymmetrical distribution of the longitudinal bars in the cross section of the column, the load-deflection curves show different hysteresis curves. When the cross section of the columns is subjected to a bending moment, the internal compressive force can be resisted by the concrete and the longitudinal bars. The longitudinal bars in the tension zone can provide the corresponding tensile force. Therefore, the hysteresis curves of the columns under a bending moment are very stable, especially demonstrated in the specimens with homogeneous distribution of reinforcing steel bars. Slight strength degradation was observed due to minor crushing of the concrete.

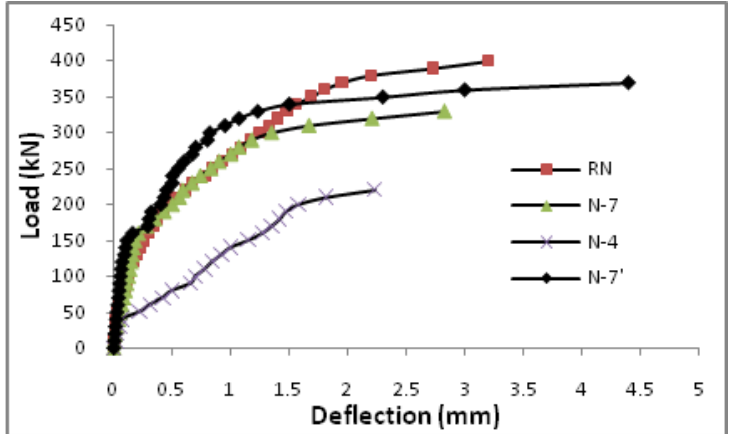

Fig. 5: Load-deflection Curves of Normal Weight Concrete Specimens

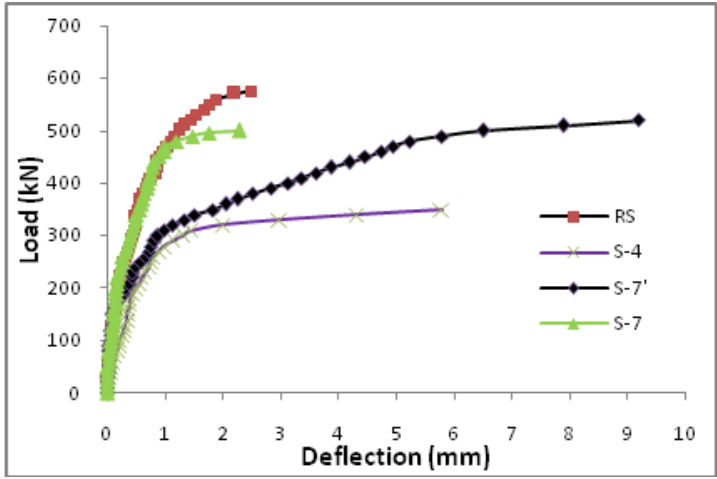

Fig. 6: Load-deflection Curves of Self-compacted Concrete Specimens

\subsection{Ultimate Load Capacity}

Columns RN and RS were cast with normal strength concrete and self- compacted concrete reinforced with $8 \varnothing 8 \mathrm{~mm}$ bar diameter used as reference columns. Table (7) shows the experimental data of tested columns under axial loading. This table appears that the ultimate capacity of references columns is $400 \mathrm{kN}$ and $575 \mathrm{kN}$ for normal strength concrete and self-compacted concrete (RN and RS) columns respectively. When replacing the longitudinal reinforcement $8 \emptyset 8 \mathrm{~mm}$ by $7 \emptyset 10$, the ultimate column capacity became $370 \mathrm{kN}$ and $520 \mathrm{kN}$ for normal strength and self compacted concrete columns (N-7' and S-7') respectively. Although reinforcing steel area is increased in $\mathrm{N}-7^{\prime}$ and $\mathrm{S}-7^{\prime}$ columns, there is $7.5 \%$ and $9.6 \%$ reduction in ultimate capacity under the control columns, since the center of gravity of steel bars will be farther from the face of the concrete from one-side, it is less efficient because the unbalance of internal couples. When a column is subjected to bending forces the greatest stress are at the edges of the column so the smaller diameter distributes the load from the concrete to the steel more effectively because the greater contact area for adhesion between steel and concrete. In addition the distribution of the bars contributes to limit the cracks by distributing the tension force throw a greater width of concrete. On the other hand, bigger bars are more brittle while smaller bars have dominant surface yield more elastic than brittle, it adds safety when failure happens.

Also, these groups contain specimen have $7 \varnothing 8 \mathrm{~mm}$ longitudinal reinforcement (three sides of the column contains one-bar at the mid space between corners and one side does not contain a longitudinal bar at the mid space between corners) although the reinforcement area is decreased in this specimen, there is a decrease in the ultimate capacity of the column about $17.5 \%$ and $13.0 \%$ for normal strength concrete and self- compacted concrete columns (N-7 and S-7) respectively.

Logically, reducing the reinforcement ratio by half contributes to decrease the load carrying capacity in normal and self compacted concrete columns about $45 \%$ and $39.13 \%$ for specimens N-4 and S-4 respectively. 
Table 7: Load Characteristics of Tested specimens

\begin{tabular}{|c|c|c|c|c|}
\hline $\begin{array}{c}\text { Specimens Sym- } \\
\text { bol }\end{array}$ & $\begin{array}{c}\text { Pu } \\
(\mathbf{k N})\end{array}$ & $\begin{array}{c}\text { Variation } \\
\text { Ratio (\%) }\end{array}$ & $\begin{array}{c}\text { Pcr } \\
(\mathbf{k N})\end{array}$ & $\begin{array}{c}\text { Variation Ratio } \\
(\%)\end{array}$ \\
\hline RN & 400 & $\mathrm{R}^{*}$ & 200 & $\mathrm{R}^{*}$ \\
\hline N-7 & 330 & 17.5 & 150 & 25 \\
\hline N-4 & 220 & 45 & 40 & 80 \\
\hline N-7 & 370 & 7.5 & 160 & 20 \\
\hline SN & 575 & $\mathrm{R}^{*}$ & 350 & $\mathrm{R}^{*}$ \\
\hline S-7 & 500 & 13 & 200 & 42.85 \\
\hline S-4 & 350 & 39.13 & 180 & 49.14 \\
\hline S-7' & 520 & 9.5 & 210 & 40 \\
\hline
\end{tabular}

\subsection{First Crack Load}

Results gained during the testing of columns specimens indicated that the first cracks appeared on the inside face at the mid height of the column. Comparison of the first crack data are shown in Table (7).

For unsymmetrical reinforced bar sections, the first crack load decreased with decreasing the number of reinforcing bars although the amount of reinforcement increased. For column specimen $(\mathrm{N}$ $\left.7^{\prime}\right)$ and (S-7'), first crack occurred in mid-height at $(160 \mathrm{kN})$ and $(210 \mathrm{kN})$ respectively. While reference column specimens $\mathrm{RN}$ and RS achieved first crack load at $(200 \mathrm{kN})$ and $(350 \mathrm{kN})$ respectively.

As expected, the first crack load decreased with decreasing the reinforcement area, $25 \%$ and $80 \%$ reduction in first crack load value caused by decreasing the number of reinforcing steel bars from $8 \Phi 8$ in reference specimen to $7 \Phi 8$ and $4 \Phi 8$ in normal concrete specimens N-7 and N-4 respectively. Similarly, the first crack load decreased $42.85 \%$ and $49.14 \%$ in self compacted concrete specimens S-7 and S-4 respectively in comparison with reference specimen RS. The appearance of first crack gives an indication about the transformation of specimen behavior from elastic to elaso-plasic state.

\subsection{Stiffness of Tested Specimens}

A column may have a stiffness $\left(\mathrm{k}=\frac{\mathrm{p}}{\mathrm{Q}}\right)$ given by where :

$\mathrm{P}:$ is the applied axial load force $(\mathrm{kN})$.

$\Delta:$ is the lateral deflection accompanied with applied axial load (mm).

Column stiffness can be defined as the rigidity of the column (the extent to which it resists deformations in response to applied load). In this investigation, it was observed that the amount of resistance to deformations in reference columns $\mathrm{RN}$ and RS higher than those columns with low reinforcement ratio and higher than that column with uneven reinforcement section (N-7' and S-7'). As shown in Table (8), the normal strength concrete specimen with $8 \Phi 8$ longitudinal reinforcement (RN) achieved stiffness about 125 $\mathrm{kN} / \mathrm{mm}$. While, the specimens with $7 \Phi 8$ and $4 \Phi 8(\mathrm{~N}-7$ and N-4) have stiffness about $116.61 \mathrm{kN} / \mathrm{mm}$ and $89.65 \mathrm{kN} / \mathrm{mm}$ respectively. Similarly, the self compacted concrete specimen with longitudinal reinforcement achieved stiffness about 230.92 $\mathrm{kN} / \mathrm{mm}$. while, the specimens with $7 \Phi 8$ and $4 \Phi 8$ (S-7 and S-4) have stiffness about $218.34 \mathrm{kN} / \mathrm{mm}$ and $60.34 \mathrm{kN} / \mathrm{mm}$ respectively.

Using amount of unsymmetrical longitudinal reinforcement greater than the longitudinal reinforcement of reference specimen contributed to the significant reduction in the stiffness. The specimens $\mathrm{N}-7^{\prime}$ and $\mathrm{S}-7^{\prime}$ with $7 \Phi 10$ longitudinal reinforcement suffered a severe decrease in stiffness about $32.7 \%$ and $75.5 \%$ respectively compared to the reference specimens RN and RS.

Table 8: Stiffness of Tested specimens

\begin{tabular}{|c|c|c|c|c|}
\hline SpecimenSymbol & Pu (kN) & $\begin{array}{c}\Delta \\
(\mathbf{m m})\end{array}$ & $\begin{array}{c}\mathrm{k} \\
(\mathbf{k N / m m})\end{array}$ & $\begin{array}{c}\text { Decreasing Ratio } \\
(\mathbf{\%})\end{array}$ \\
\hline $\mathrm{RN}$ & 400 & 3.2 & 125 & $\mathrm{R}^{*}$ \\
\hline $\mathrm{N}-7$ & 330 & 2.83 & 116.61 & 6.7 \\
\hline $\mathrm{N}-4$ & 220 & 2.23 & 98.65 & 21.1 \\
\hline
\end{tabular}

\begin{tabular}{|c|c|c|c|c|}
\hline N-7 & 370 & 4.4 & 84.1 & 32.7 \\
\hline RS & 575 & 2.49 & 230.92 & $\mathrm{R}^{*}$ \\
\hline S-7 & 500 & 2.29 & 218.34 & 5.44 \\
\hline S-4 & 350 & 5.8 & 60.34 & 73.87 \\
\hline S-7' & 520 & 9.2 & 56.52 & 75.5 \\
\hline
\end{tabular}

\subsection{Comparison of Theoretical and Experimental Re- sults}

\section{Analytical modeling}

Model analysis was carried out using ANSYS (version 10) software. The deflection during the loading, load carrying capacity and first crack load were extracted from the analysis output.

\subsubsection{Element type}

The column specimen was modeled in ANSYS (version 10) with link 8 and solid 65 elements. The link 8 element was adopted to simulate reinforcement and the solid 65 element was adopted to simulate the concrete.

\subsubsection{Material properties}

Material model number one indicates to solid 65 elements which is used to model the concrete. PRXY is the poisson ratio and EX is the modulus of elasticity of concrete. For normal weight concrete, the dry unit weight is $(2380 \mathrm{~kg} / \mathrm{m} 3)$. For self-compacted concrete, the dry unit weight is $(3265 \mathrm{~kg} / \mathrm{m} 3)$. Material model number (2) indicates to link 8 element, Figure (7) is adopted to define the stress- strain relationship of reinforcing steel. This curve passes in two stages, stage (1) start at the origin up to yield stress (fy) with slope Es. Stage (2) have very small slope up to $(\mathrm{Fu})$. The shear transfer coefficient use to model the condition of the cracks, it ranged between 0-1, o value of shear transfer coefficient indicating a smooth crack and (1) value of shear transfer coefficient indicating a rough crack, the shear transfer coefficient is taken to be (1). The crushing coefficient is taken to be (0) to permitting the capability of the concrete element to crush. The compression strength, modulus of rupture, tensile strength and modulus of elasticity were taken from experimental work results.

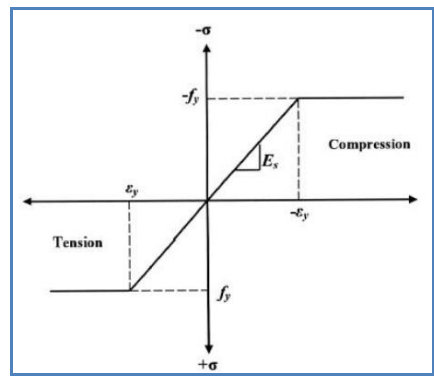

Fig. 7: Stress-Strain Curve for Steel Reinforcemen

\subsubsection{Load-deflection curves}

Figures (8) to (15) indicate the evaluation of lateral deflection with applied load both for theoretical and experimental results. The results of theoretical work show good agreement with experimental results.

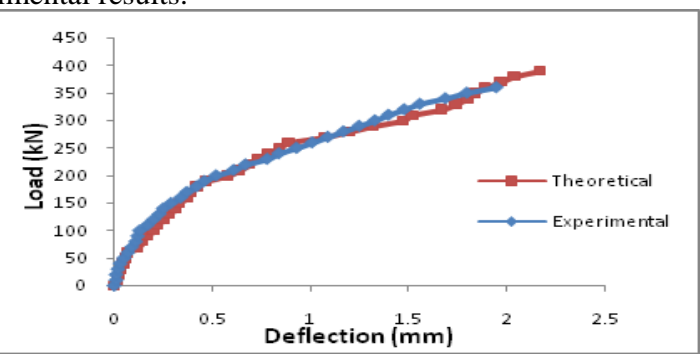

Fig. 8: Load-deflection Curves of Reference Specimen RN 


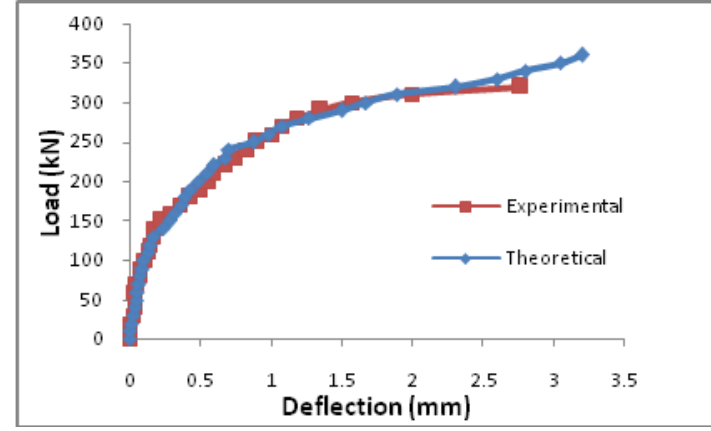

Fig. 9: Load-deflection Curves of Reference Specimen N-7

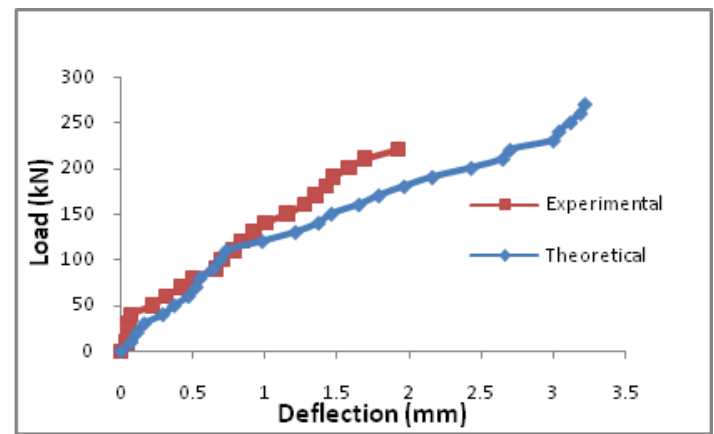

Fig. 10: Load-deflection Curves of Reference Specimen N-4

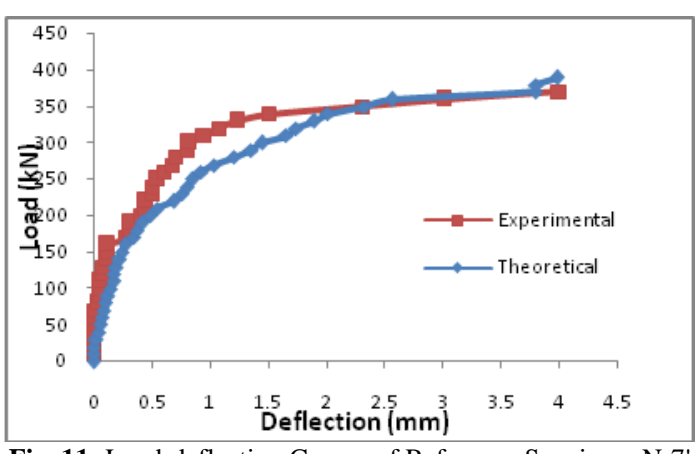

Fig. 11: Load-deflection Curves of Reference Specimen N-7

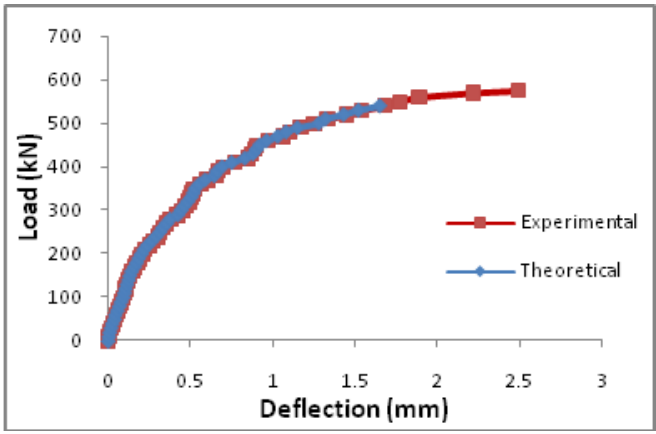

Fig. 12: Load-deflection Curves of Reference Specimen RS

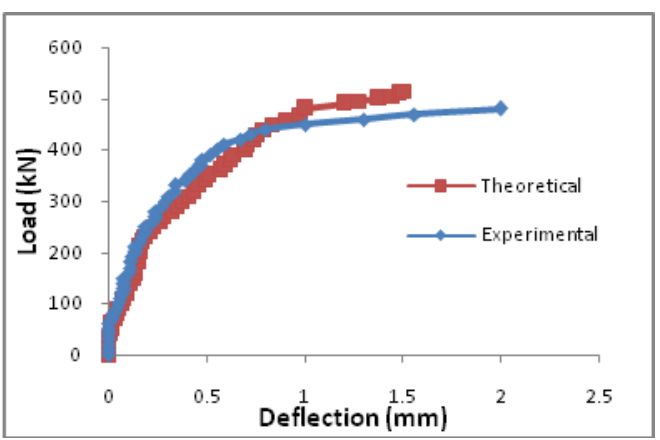

Fig. 13: Load-deflection Curves of Reference Specimen S-7

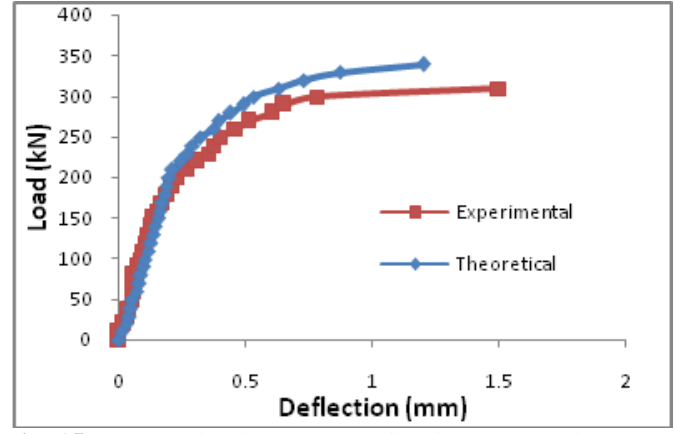

Fig. 15: Load-deflection Curves of Reference Specimen S-7'

\subsubsection{Ultimate and Cracking Load}

Table (9) shows the experimental and theoretical of ultimate and first crack loads, and the correlation between the theoretical and experimental results is also indicated in this table. It was noted that there was a very acceptable convergence between experimental and theoretical results.

Table 9: Theoretical and Experimental Results of Ultimate Load and First Crack Load

\begin{tabular}{|c|c|c|c|c|c|c|}
\hline \multirow{2}{*}{$\begin{array}{c}\text { Specimen } \\
\text { Config. }\end{array}$} & \multicolumn{2}{|c|}{ Pu (kN) } & \multirow{2}{*}{$\frac{\text { Pu exp }}{\text { pu the. }}$} & \multicolumn{2}{|c|}{$\operatorname{Pcr}(k N)$} & \multirow{2}{*}{$\frac{\text { Pcr exp }}{\text { pcr the }}$} \\
\hline & Exp. & The. & & Exp. & The. & \\
\hline $\mathrm{RN}$ & 400 & 412 & 0.97 & 200 & 211 & 0.94 \\
\hline $\mathrm{N}-7$ & 330 & 346 & 0.95 & 150 & 162 & 0.92 \\
\hline $\mathrm{N}-4$ & 220 & 236 & 0.93 & 40 & 44 & 0.9 \\
\hline N-7' & 370 & 389 & 0.95 & 160 & 169 & 0.94 \\
\hline $\mathrm{SN}$ & 575 & 592 & 0.97 & 350 & 364 & 0.96 \\
\hline S-7 & 500 & 515 & 0.97 & 200 & 218 & 0.91 \\
\hline S-4 & 350 & 356 & 0.98 & 180 & 185 & 0.97 \\
\hline S-7' & 520 & 530 & 0.98 & 210 & 223 & 0.94 \\
\hline
\end{tabular}

\section{Conclusion}

Depending on the results obtained from the experimental and theoretical works, the following conclusions can be illustrated:

Using amount of unsymmetrical longitudinal reinforcement greater than that of symmetrical longitudinal reinforcement contributed to the significant reduction in the stiffness.

Although the amount of reinforcement increased for unsymmetrical reinforced bar sections, the first crack load decreased with decreasing the number of reinforcing bars.

Although reinforcing steel area is increased in unsymmetrical reinforced bar sections, there is a reduction in ultimate capacity under the reference columns.

The load-deflection curves of all columns specimens passes in three stages: the first linear stage, the second linear stage and third nonlinear stage.

All columns specimens failed by crushing at top and bottom of tested specimens, the distribution of reinforcing steel bars didn't effect on the failure pattern of tested columns.

The results of theoretical work show good agreement with experimental results.

\section{References}

[1] Watson, S. and Zahn, F. A., 1994,' Confining Reinforce -ment for Concrete Columns' Journal of Structural Engineering-ASCE, 120 (6), June, 1798-1824.

[2] Bai, Y. L., Dai, J. G., Teng, J. G., 2012, " Experimental Study on the Buckling Behavior of Reinforcing Bars in FRP- confined RC Columns" The 15th World Conference on Earthquake Engineering, Lisbon, Portugal.

[3] Patrick, P., Kamal, K., Daniel, C., and Stephan T., 2005,' Structural Performance of Self-Consolidating Concrete Used in Confined Concrete Columns', ACI Structural Journal, 102 (4), 560-568.

[4] Omar, M. Y. M., Gomes, R. B. and Reis, A. P. A., 2010,' Experimental Analysis of Reinforced Concrete Columns Strengthened 
with Self-Compacting Concrete', Ibracon Structures and Materials Journals, 3 (3), 271-283.

[5] Silvia, R., Nestore, G. and Antonio, N., 2006 ,' Large-Size Reinforced Concrete Columns Strengthened with Carbon FRP: Experimental Evaluation', Third International Conference on FRP Composites in Civil Engineering (CICE 2006), 13-15 December, Miami, Florida, USA

[6] Chikh, N., Gahmous , M. and Benzaid, R., 2012, ' Structural Performance of High Strength Concrete Columns Confined with CFRP Sheets', Proceedings of the World Congress on Engineering, 4 - 6 July, London, U.K.

[7] Preekanth, L. D., Subrahmanya, R. M. and Naresh Kumar, B. G., 2015, 'Study on the Behavior of Rectangular Column with Unequally Spaced Longitudinal Reinforcement', International Journal of Engineering Research and Technology (IJERT), 4(07), July, 36-45.

[8] Vigneshvar,R.,Hareesh, M and Sekar, S.K.,2017,' Analysis of Tensile Capacity of Reinforced Concrete Columns and Its Ductility Performance Towards Seismic Behavior', International Journal of Civil Engineering and Technology, 8(08), 798-806.

[9] Tirath, M. P., Paulus, I. and Koichi, M., 1995,' Effectiveness of Laterally Arranged Reinforcement on the Confinement of Core Concrete', Journal of Materials, Concrete, Structures and Pavements, 28(520), 297-308.

[10] Haider, O. A., 2013,' Strength and Ductility of Axially Loaded RC Short Columns Confined with CFRP and GFRP Wraps', MSc Thesis, University of Sharjah, UAE, Sharjah, $117 \mathrm{P}$.

[11] ASTM C39-86, 2003, " Test Method for Compressive Strength of Cylindrical Concrete Specimens", ASTM International.

[12] BS 1881: Part 116: 1983, "Method for Determination of Compressive Strength of Concrete Cubes", Park Street, London, International British Standard.

[13] BS (1881): Part 117, 1983," Method of Determination of Tensile Splitting Strength", London, International British Standard. 